\title{
A Study the Farm Asset Structures, Cropping Pattern and Cropping Intensity of Sample Farms
}

\section{Rajeev Kumar*, Rajeev Singh, Gyan Prakesh Singh, Harendra Pratap Singh Choudhri, Jitendra Kumar Singh and Santosh Kumar Mishra}

\author{
Department of Agricultural Economics, N.D.U.A. \& T. \\ Kumarganj, Faizabad-224229, U.P., India \\ *Corresponding author
}

\section{A B S T R A C T}

\section{Keywords}

Weighted mean and Tabular analysis.

Article Info

Accepted:

26 August 2017

Available Online:

10 September 2017
Keeping in view the importance of the vegetable crops in nutritional security and generating the income and employment to the farm population a study on economics of cauliflower cultivation in Chiraigaon block of Varanasi district of U.P. was conducted in agriculture year 2016-2017. Stratified purposive cum random sampling technique was applied to select the sample respondents' primary data were collected through interview method. Tabular and function analysis was done to present the result. Overall average size of holding was 0.78 ha. Which were 0.56 ha 1.19 ha and 2.76 ha. At marginal, small and medium size of farms respectively. Per farm and per hectare investment on sample farms was of positive trend with size of holding. Cost of cultivation and different income measures were also had the positive trend with size of farms. Output - Input ratio were $1: 1.98,1: 2.02$, and 1:2.11 on marginal, small and medium size group of farm which was recorded as 1:2.00 at overall farm. Cauliflower cultivation was found profitable on each size group of farms and it was characterized of decreasing returns to scale as sum of elasticity were less than one in all categories of farms. Value of multiple coefficient of determination $\left(\mathrm{R}^{2}\right)$ shows $93.65,80.67$ and 95.87 per cent variation in output due to all included input factors in study. MVP of all the input factors in every farms size except few were more than one which showed the further possibility of increased expenditure to receive additional profit. Technical, managerial, financial and miscellaneous problem were faced by the sample farmers which were suggested to solve by having some extension activities as and when possible and little more support of financial institution for credit. At last cauliflower cultivation was found more suitable for the farmers of the studv area.

\section{Introduction}

Indian subcontinent has been endowed by nature with vast diversity of land, soil and agro-climate condition found suitable to produce various types of vegetable crops. There is substantial increase in production and productivity of vegetables crop. The area and production of vegetables are increasing year after the green revolution, owing to growing of improved varieties and adoption of improved cultivation technologies. Further, the country has made quantum jump since independence scoring more than seven times increase in vegetables production.

However, the production of different vegetables is comparatively low in comparison with that of other developed countries. 
Most of the developing countries of the world including India, population is growing rapidly than food availability. In turns these countries are struggling with the problem of protein and calories. Malnutrition which is easily visible among the vulnerable of coming decade is not only to provide more food to meet calories need of our burgeoning population but it is equally important to make availability of low cost protein and vitamin. Even in advanced countries like America where animal protein and milk product are available in abundance.

Cauliflower is one of the most important winter vegetables in India. It was introduced in India during 1822 from France. Cauliflower is grown for its tender head or curd. It is a delicate crop and needs more care to grow successfully than most of the other vegetable. It can be grown in all types of soil with good fertility and good water regime. However, for early crops, in tropical and subtropical regions, a light to light medium soil may be preferred so that the drainage is easier in the rainy season. Therefore, in the cultivation of Cauliflower steady growth is important since rampart growth may retard the formation of curd and it may also slow the growth of bracts. Under the Indian conditions, especially in North India the mid-season crop and late crop will grow very well in medium heavy and heavy soils when temperature is $10-16^{0} \mathrm{C}$ for curd formation. In the plain region of India, it is available from September to May. The optimum $\mathrm{pH}$ for cauliflower cultivation is 6-6.5. However, it has been reported that maximum yield of cauliflower is obtained at soil having $\mathrm{pH}$ between 5.5 and 6.5. Cauliflower is sensitive to high acidity. It is delicious cool season vegetable. The head is eaten while the stalk and surrounding thick, green leaves are used in vegetable broth or discard.

India is the second largest producer of Cauliflower in the world after China followed by Italy, France and Spain. Cauliflower cover an area of 414 mha in India, its production is 7897 million tonnes and productivity is 19.1 tonnes/ha which constitutes $21.92 \%$ of world Cauliflower production. Production of China is 806 million tonnes and worldwide highest productivity recorded in Japan. In India, major Cauliflower producing State are West Bengal, Orissa, Bihar, Maharashtra and Assam. In Uttar Pradesh during 2014 area, production and productivity of Cauliflower was reported $10.15 \mathrm{mha}, 222.62$ million tonnes and 21.9 tonnes/ha, respectively. In district Varanasi, area, production and productivity of Cauliflower were reported 356 ha, 7223 tonnes and 20 tonnes/ha, respectively (Anonymous 2015).

Within last two decades the production of vegetables in India has increased two times. More than 40 types of vegetables belonging to different groups namely solanaceous,

Cucurbitaceous, leguminous, cruciferous (Cole crops) root crops and leafy vegetables are grown in India in tropical subtropical and temperate regions.

Vegetables play an important role in balanced nutrition for human being as they are valuable source of proteins, vitamins and minerals. The per capita consumption of vegetables in India is $170 \mathrm{~g}$ per day per person as against recommendation of $280 \mathrm{gm}$ per day per person (Food and Agriculture Organization, India). At present, more than $65 \%$ of our population is engaged in agriculture over an area of 320 mha out of these hardly about $1-2 \%$ of the total cultivated area is under vegetable crop. These figures showed the necessity of vegetable cultivation on large area to fulfill the required quantity of vegetable for balance diet. It is comparatively more remunerative crop than field crops. The wider adaptability of vegetables to different kinds of abiotic stresses like water, soil, weather offer the 
possibility to increase the acreage under these crops.

Fresh Cauliflower is an excellent source of vitamins, its $100 \mathrm{gm}$ provide about $48.2 \mathrm{mg}$ or $80 \%$ daily recommended value vitamin-C is a proven antioxidant that helps to fight against harmful free radical.

It contains good amount of many vitamin-B complex group of vitamins, such as floats pantothenic acid (vitamin $\mathrm{B}_{1}$ ) niacin $\left(\mathrm{B}_{3}\right)$, as well as, vitamin $\mathrm{K}$. These vitamins are in the sense that body requires them from external source to replenish. Further it is good source of minerals, such as, Mn is used in the body as co-factor for the antioxidant enzyme. (Anonymous 2016)

Cauliflower is a crop which is grown three times in a year as early, mid \& late season crops which further offer great opportunity of income an employment generation to the community mainly involves in its cultivation. Since, prices of inputs like seeds, manures, fertilizer, chemical, irrigation and labour charges are increasing every year.

Thus it is of utmost importance to study the economics of Cauliflower cultivation, in order to present the real scenario of economic Cauliflower cultivation. Keeping in view of these facts the study entitled "Study on Economics of Cauliflower cultivation in Chiraigaon block of Varanasi district.

\section{Materials and Methods}

Methodological aspect of study on Economics of Cauliflower cultivation has been discussed under the following four heads.

Sampling technique.

Collection of data and method of enquiry.

Period of enquiry.

Analytical tools

\section{Sampling technique}

Multistage stratified purposive cum random sampling technique was used for the selection of District, Block, Villages and Respondents (Cauliflower grower).

\section{Selection of district}

In the first stage Varanasi District of Utter Pradesh was selected purposively because of large amount of vegetable trading takes place in Varanasi.

\section{Selection of block}

There were 8 Blocks in Varanasi district i.e.

i) Arajiline, ii) Baragaon, iii) Chiraigaon, iv) Harhua v) Cholapur, vi) Kashi Vidyapith, vii) Pindara, viii) Sewapuri

Out of 8 Blocks of Varanasi District 1 block namely Chiraigaon was selected purposively where Cauliflower grower are in large numbers.

\section{Selection of villages}

Out of 94 villages of selected block5 Villages namely Bariyasanpur, Gaurakala, Rustampur, Chiraigaon and Umarahan were selected purposively where maximum number of farmers grow Cauliflower on large scale.

\section{Selection of farmers/growers}

A separate list of Cauliflower growers of selected villages was prepared along-with their size of holding obtained from record (Khasara and Khatauni) available at Tehsil level and further it was grouped into three categories i.e.

Marginal farmer $(<1$ ha)

Small farmer (1-2 ha)

Medium farmer (2-4ha) 
At last 100 respondents were selected following the proportionate random sampling technique.

\section{Collection of data and method of enquiry}

\section{Primary data}

The primary data on production aspects were collected on well prepared schedule by survey method.

Frequent visits were done by the investigator to the selected respondents and required data were recorded by personal interview.

Accuracy of the data was assured through cross-checking.

\section{Secondary data}

The secondary information was compiled from the published report at Block, Tehsil and District offices.

\section{Period of enquiry}

The data were collected to the main-season crop of the 2016-2017.

\section{Analytical tools}

The data collected from the sample cultivators were analyzed and estimated with certain statistical techniques which are mentioned below.

\section{Weighted average}

The simplest and important measures of average which have been used into statistical analysis were the weighted average. The formula used to estimate the weighted average is:

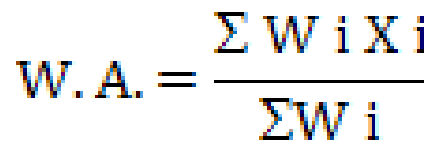

Where,

W. A. = Weighted average

$\mathrm{X}_{\mathrm{i}}=$ Variable

$\mathrm{W}_{\mathrm{i}}=$ Weights of $\mathrm{X}_{\mathrm{i}}$

$\mathrm{Y}=$ per hectare output (Rs.)

\section{Results and Discussion}

This section deals with the findings of present investigation with the distribution of land, cropping pattern, cropping intensity, and farm assets structure.

\section{The structure of sample farms}

This section deals with the size of farms, irrigational structure, cropping pattern, cropping intensity and farm assets.

\section{Average size of holding on sample farms}

The details of land holding owned by the sample farmers under different size group of sample farms are given in table 1.

It is revealed from the table that the average size of holding of marginal, small and medium farms were found 0.56, 1.19 and 2.76 hectares respectively.

The overall average size of holding in study area was found to be 0.78 hectare.

The table also indicates that about 58.60 percent of the cultivated area was owned by percent of the sample farms whereas 16.72 and 24.68 per cent of that where owned by 11 and 7 percent of the farms owners this reflect that optimum combination of family labour with holding size does not exist an sample farm. 


\section{Cropping pattern}

Cropping pattern presents the area devoted to the various crop during the given period, conventionally in a single year. It indicates the yearly sequence and arrangement of crops grown by farmer in a particular area. The cropping patterns followed by the sample farms are presented in table 2 .

It is depicted from the table 2 that on an average the highest area was covered under wheat 16.18 per cent followed by paddy 14.47 per cent, urd 7.18 per cent, cauliflower 7.14 per cent, cucumber 6.84 , maize 6.73 per cent, pumpkin 6.35 per cent, chilli 4.26 per cent, tomato 4.13 , okara 4.12 per cent, chari 3.93 per cent potato 3.87 per cent, mustard 3.18 per cent, berseem 3.27 per cent, brinjal 3.12 per cent, radish 2.40 per cent and Chick pea 2.32 per cent of total cropped area on the sample farms. Wheat and paddy are the main crop raised on sample farms.

It is revealed from the table that among various vegetable crops cauliflower had been allotted highest area i.e. 7.14 percent of the gross cropped area. It is a justifiable feature of the cropping pattern that in all three seasons i.e. Kharif, Rabi and Zaid vegetable crops have been provided with considerable share in cultivation area as it was supported with a nice facilities of agricultural market like existence of shabji Mandi near to the farmers' field and better road and transport facility etc.

It is depicted from the table that the total area covered under different vegetable crops were 13.90, 11.01 and 17.32 per cent of gross cropped area in Kharif, Rabi and Zaid seasons respectively, grain crops included in cropping pattern i.e. paddy, wheat and maize.

The gross cultivated area was higher in the Rabi season and less in the Kharif season on all farm situations.
Marginal farmers devoting highest area for cultivation of cauliflower 8.52 per cent followed by small farmers 6.55 per cent and medium 3.65 per cent, respectively of their total cultivated area.

\section{Cropping intensity}

The details of cropping intensity are given in the table. Table 3 reveals that the overall average cropping intensity on sample farms was 255.12 per cent which was found highest on marginal farms 272.32 percent followed by small 230.25 per cent and medium 228.26 per cent, respectively.

Higher cropping intensity on marginal farm was found due to better utilization of family labour in intensive labour requirement of vegetable crops.

\section{Farm asset structure on sample farms}

\section{Per farm investment}

The success of farming mostly depends on the availability of fixed capital is on the farm the types of enterprise and system of farming is influenced by the availability of capital.

Thus the fixed capital is an important factor of production, which varies from farm to farm depending upon size of farm business. The capital investment on fixed assets on different size group of selected farm have been classified under i) Farm building ii) Farm machinery and implement and livestock.

Table 4 presents the per-farm asset structure on sample farms. It is evident from this table that major components of farm asset structure are Buildings, Machinery and implements and live-stocks which constituted 64.09 percent, 22.43 percent and 13.48 percent of total asset value, respectively on the basis of overall average. 
Table.1 Average holding size of sample farmers under different size group of farms

\begin{tabular}{|l|l|c|c|c|}
\hline Sl. No. & Size groups (ha) & No. of farmers & Net cultivated area (ha) & Average size of farms \\
\hline 1. & Marginal farmers & 82 & $45.94(58.60)$ & 0.56 \\
\hline 2. & Small farmers & 11 & $13.11(16.72)$ & 1.19 \\
\hline 3. & Medium farmers & 7 & $19.34(24.68)$ & 2.76 \\
\hline Grand Total & $\mathbf{1 0 0}$ & $\mathbf{7 8 . 3 9}(\mathbf{1 0 0})$ & $\mathbf{0 . 7 8}$ \\
\hline
\end{tabular}

Table. 2 Cropping pattern under different size group of sample farms (ha)

\begin{tabular}{|c|c|c|c|c|c|}
\hline \multirow[t]{2}{*}{ Sl. No. } & \multirow[t]{2}{*}{ Crop } & \multicolumn{3}{|c|}{ Average size of sample farms } & \multirow{2}{*}{$\begin{array}{l}\text { Overall } \\
\text { Average }\end{array}$} \\
\hline & & Marginal & Small & Medium & \\
\hline A. & Kharif & $\begin{array}{c}0.52 \\
(34.43)\end{array}$ & $\begin{array}{c}1.03 \\
(37.5)\end{array}$ & $\begin{array}{c}2.30 \\
(36.50)\end{array}$ & $\begin{array}{c}\mathbf{0 . 7 0} \\
(35.35)\end{array}$ \\
\hline 1. & Paddy & $\begin{array}{c}0.20 \\
(13.16)\end{array}$ & $\begin{array}{c}0.40 \\
(14.60)\end{array}$ & $\begin{array}{c}1.15 \\
(18.30)\end{array}$ & $\begin{array}{c}0.28 \\
(14.47)\end{array}$ \\
\hline 2. & Maize & $\begin{array}{l}0.113 \\
(7.45)\end{array}$ & $\begin{array}{c}0.15 \\
(5.46)\end{array}$ & $\begin{array}{c}0.36 \\
(5.71)\end{array}$ & $\begin{array}{c}0.13 \\
(6.73)\end{array}$ \\
\hline 3. & Chilli & $\begin{array}{l}0.073 \\
(4.78)\end{array}$ & $\begin{array}{c}0.08 \\
(3.24)\end{array}$ & $\begin{array}{c}0.22 \\
(3.49)\end{array}$ & $\begin{array}{c}0.08 \\
(4.26)\end{array}$ \\
\hline 4. & Brinjal & $\begin{array}{c}0.04 \\
(2.67)\end{array}$ & $\begin{array}{c}0.14 \\
(5.10)\end{array}$ & $\begin{array}{c}0.20 \\
(3.17)\end{array}$ & $\begin{array}{c}0.06 \\
(3.12)\end{array}$ \\
\hline 5. & Radish & $\begin{array}{l}0.035 \\
(2.39)\end{array}$ & $\begin{array}{c}0.06 \\
(2.22)\end{array}$ & $\begin{array}{c}0.18 \\
(2.86)\end{array}$ & $\begin{array}{c}0.04 \\
(2.40)\end{array}$ \\
\hline 6. & Okara & $\begin{array}{c}0.06 \\
(3.98)\end{array}$ & $\begin{array}{c}0.18 \\
(6.55)\end{array}$ & $\begin{array}{c}0.19 \\
(3.02)\end{array}$ & $\begin{array}{c}0.08 \\
(4.12)\end{array}$ \\
\hline B. & Rabi & $\begin{array}{c}0.52 \\
(34.1)\end{array}$ & $\begin{array}{c}1.12 \\
(40.80)\end{array}$ & $\begin{array}{c}2.42 \\
(38.40)\end{array}$ & $\begin{array}{c}0.71 \\
(36.06)\end{array}$ \\
\hline 1. & Wheat & $\begin{array}{c}0.21 \\
(13.77)\end{array}$ & $\begin{array}{c}0.49 \\
(17.80)\end{array}$ & $\begin{array}{c}1.38 \\
(21.90)\end{array}$ & $\begin{array}{c}0.32 \\
(16.18)\end{array}$ \\
\hline 2. & Cauliflower & $\begin{array}{c}0.13 \\
(8.52)\end{array}$ & $\begin{array}{c}0.18 \\
(6.55)\end{array}$ & $\begin{array}{c}0.23 \\
(3.65)\end{array}$ & $\begin{array}{c}0.14 \\
(7.14)\end{array}$ \\
\hline 3. & Mustard & $\begin{array}{l}0.049 \\
(3.21)\end{array}$ & $\begin{array}{c}0.12 \\
(4.37)\end{array}$ & $\begin{array}{c}0.17 \\
(2.78)\end{array}$ & $\begin{array}{c}0.06 \\
(3.18)\end{array}$ \\
\hline 4. & Chick Pea & $\begin{array}{l}0.032 \\
(2.09)\end{array}$ & $\begin{array}{c}0.09 \\
(3.28)\end{array}$ & $\begin{array}{c}0.14 \\
(2.35)\end{array}$ & $\begin{array}{c}0.04 \\
(2.32)\end{array}$ \\
\hline 5. & Potato & $\begin{array}{l}0.053 \\
(3.47)\end{array}$ & $\begin{array}{c}0.16 \\
(5.83)\end{array}$ & $\begin{array}{c}0.23 \\
(3.65)\end{array}$ & $\begin{array}{c}0.07 \\
(3.87)\end{array}$ \\
\hline 6. & Barseem & $\begin{array}{l}0.045 \\
(2.95)\end{array}$ & $\begin{array}{c}0.09 \\
(3.39)\end{array}$ & $\begin{array}{c}0.26 \\
(4.13)\end{array}$ & $\begin{array}{c}0.06 \\
(3.27)\end{array}$ \\
\hline C. & Zaid & $\begin{array}{c}0.478 \\
(31.48)\end{array}$ & $\begin{array}{l}0.596 \\
(21.7)\end{array}$ & $\begin{array}{c}1.58 \\
(25.10)\end{array}$ & $\begin{array}{c}0.56 \\
(28.58)\end{array}$ \\
\hline 1. & Urd & $\begin{array}{c}0.11 \\
(7.24)\end{array}$ & $\begin{array}{c}0.15 \\
(5.54)\end{array}$ & $\begin{array}{c}0.52 \\
(8.25)\end{array}$ & $\begin{array}{c}0.14 \\
(7.18)\end{array}$ \\
\hline 2. & Cucumber & $\begin{array}{l}0.118 \\
(7.74)\end{array}$ & $\begin{array}{c}0.14 \\
(5.24)\end{array}$ & $\begin{array}{c}0.34 \\
(5.40)\end{array}$ & $\begin{array}{c}0.13 \\
(6.84)\end{array}$ \\
\hline 3. & Pumpkin & $\begin{array}{l}0.116 \\
(7.67)\end{array}$ & $\begin{array}{c}0.08 \\
(3.24)\end{array}$ & $\begin{array}{c}0.31 \\
(4.92)\end{array}$ & $\begin{array}{c}0.12 \\
(6.35)\end{array}$ \\
\hline 4. & Chari & $\begin{array}{l}0.068 \\
(4.45)\end{array}$ & $\begin{array}{c}0.11 \\
(4.01)\end{array}$ & $\begin{array}{c}0.15 \\
(2.38)\end{array}$ & $\begin{array}{c}0.07 \\
(3.93)\end{array}$ \\
\hline 5. & Tomato & $\begin{array}{l}0.066 \\
(4.38)\end{array}$ & $\begin{array}{c}0.13 \\
(4.73)\end{array}$ & $\begin{array}{c}0.24 \\
(3.94)\end{array}$ & $\begin{array}{c}0.08 \\
(4.13)\end{array}$ \\
\hline Tota & $A+B+C)$ & $1.525(100)$ & $2.74(100)$ & $6.30(100)$ & $1.99(100)$ \\
\hline
\end{tabular}

(Figure in parentheses indicate the percentage) 
Table.3 Cropping intensity on different size group of sample farms

\begin{tabular}{|l|l|c|c|c|c|}
\hline $\begin{array}{l}\text { S. } \\
\text { No. }\end{array}$ & $\begin{array}{l}\text { Size group } \\
\text { of farms }\end{array}$ & $\begin{array}{c}\text { No, of } \\
\text { sample } \\
\text { farms }\end{array}$ & $\begin{array}{c}\text { Net } \\
\text { Cultivated } \\
\text { area (ha) }\end{array}$ & $\begin{array}{c}\text { Gross } \\
\text { Cropped } \\
\text { area (ha) }\end{array}$ & $\begin{array}{c}\text { Cropping } \\
\text { intensity } \\
(\%)\end{array}$ \\
\hline 1. & Marginal & 82 & 0.56 & 1.525 & 272.32 \\
\hline 2. & Small & 11 & 1.19 & 2.74 & 230.25 \\
\hline 3. & Medium & 7 & 2.76 & 6.30 & 228.26 \\
\hline & Average & 100 & 0.78 & 1.99 & 255.12 \\
\hline
\end{tabular}

(Figure in parentheses indicate the percentage)

Table.4 Per farm investment on different size group of sample farms (Rs.)

\begin{tabular}{|l|l|c|c|c|c|}
\hline \multirow{2}{*}{ S. } & \multirow{2}{*}{ Particulars } & \multicolumn{4}{|c|}{ Size of farms } \\
\cline { 2 - 6 } & & Marginal & Small & Medium & Overall average \\
\hline 1. & Buildings & $\mathbf{2 4 0 0 3 6 . 6 7}$ & $\mathbf{2 6 8 9 9 9 . 9 9}$ & $\mathbf{2 8 5 4 2 8 . 1 4}$ & $\mathbf{2 4 6 4 0 0 . 0 3}$ \\
& & $\mathbf{( 6 7 . 1 5 )}$ & $\mathbf{( 5 4 . 0 6 )}$ & $\mathbf{( 5 4 . 5 1 )}$ & $\mathbf{( 6 4 . 0 9 )}$ \\
\hline a. & Residential & 208585.36 & 235909.09 & 247000 & 214279.99 \\
& & $(58.36)$ & $(47.41)$ & $(47.18)$ & $(55.73)$ \\
\hline b. & Cattle shed & 31451.21 & 33090.90 & 38428.14 & 32119.96 \\
& & $(8.79)$ & $(6.65)$ & $(7.34)$ & $(8.35)$ \\
\hline 2. & Machinery and & $\mathbf{7 0 6 9 3 . 0 1}$ & $\mathbf{1 5 4 9 9 0 . 3 6}$ & $\mathbf{1 6 0 5 7 9 . 4 5}$ & $\mathbf{8 6 2 5 7 . 7 6}$ \\
& Implements & $\mathbf{( 1 9 . 7 8 )}$ & $\mathbf{( 3 1 . 1 5 )}$ & $\mathbf{( 3 0 . 6 7 )}$ & $\mathbf{( 2 2 . 4 3 )}$ \\
\hline a. & Major & 70410.12 & 154677.00 & 160254.00 & 58968.54 \\
& Implements & $(19.70)$ & $(31.08)$ & $(30.61)$ & $(22.36)$ \\
\hline b. & Minor & 282.89 & 313.36 & 325.45 & 289.22 \\
& Implements & $(0.08)$ & $(0.06)$ & $(0.062)$ & $(0.07)$ \\
\hline 3. & Live stock & $\mathbf{4 6 7 0 9 . 2 2}$ & $\mathbf{7 3 6 0 9 . 0 8}$ & $\mathbf{7 7 5 7 1 . 4}$ & $\mathbf{5 1 8 2 8 . 5 5}$ \\
& & $\mathbf{( 1 3 . 0 7 )}$ & $\mathbf{( 1 4 . 7 9 )}$ & $\mathbf{( 1 4 . 8 2 )}$ & $\mathbf{( 1 3 . 4 8 )}$ \\
\hline a. & Buffalo & 21548.79 & 42909.09 & 41714.26 & 25310.01 \\
& & $(6.03)$ & $(8.62)$ & $(7.97)$ & $(6.58)$ \\
\hline b. & Cow & 19231.17 & 25545.45 & 28857.14 & 20599.56 \\
& & $(5.38)$ & $(5.13)$ & $(5.51)$ & $(5.35)$ \\
\hline c. & Goat & 5497.56 & 4909.09 & 7000.00 & 5537.99 \\
& & $(1.53)$ & $(0.99)$ & $(1.34)$ & $(1.44)$ \\
\hline d. & Poultry & 431.70 & 245.45 & 00.00 & 380.99 \\
& & $(0.13)$ & $(0.049)$ & $(00.00)$ & $(0.09)$ \\
\hline 4. & Grand total & $\mathbf{3 5 7 4 3 8 . 8 0}$ & $\mathbf{4 9 7 5 9 9 . 4 3}$ & $\mathbf{5 2 3 5 7 8 . 9 9}$ & $\mathbf{3 8 4 4 8 6 . 2 8}$ \\
& & $\mathbf{( 1 0 0 )}$ & $\mathbf{( 1 0 0 )}$ & $\mathbf{( 1 0 0 )}$ & $\mathbf{( 1 0 0 )}$ \\
\hline
\end{tabular}

(Figure in parentheses indicate the percentage) 
Table.5 Per hectare investment on different size group of sample farms (Rs.)

\begin{tabular}{|l|l|c|c|c|c|}
\hline S. & Particulars & \multicolumn{4}{|c|}{ Size of farms } \\
\cline { 3 - 6 } No. & & Marginal & Small & Medium & Overall average \\
\hline $\mathbf{1 .}$ & Buildings & $\mathbf{4 2 8 6 3 6 . 7 0}$ & $\mathbf{3 0 2 2 4 7 . 2 0}$ & $\mathbf{1 4 4 8 8 7 . 4 0}$ & $\mathbf{3 9 4 8 7 1 . 4 3}$ \\
& & $\mathbf{( 6 7 . 1 5 )}$ & $\mathbf{( 5 4 . 0 6 )}$ & $\mathbf{( 5 4 . 5 1 )}$ & $\mathbf{( 6 5 . 4 3 )}$ \\
\hline a. & Residential & 372473.90 & 265066.40 & 125380.70 & 343362.52 \\
& & $(58.36)$ & $(47.40)$ & $(47.17)$ & $(56.9)$ \\
\hline b. & Cattle shed & 56162.88 & 37180.79 & 19506.67 & 51508.91 \\
& & $(8.80)$ & $(6.65)$ & $(7.33)$ & $(8.53)$ \\
\hline 2. & Machinery and & $\mathbf{1 2 6 2 3 7 . 5 0}$ & $\mathbf{1 7 4 1 4 6 . 5 0}$ & $\mathbf{8 1 5 1 2 . 4 1}$ & $\mathbf{1 2 8 3 7 6 . 7 5}$ \\
& Implements & $\mathbf{( 1 9 . 7 8 )}$ & $\mathbf{( 3 1 . 1 4 )}$ & $\mathbf{( 3 0 . 6 7 )}$ & $(\mathbf{2 1 . 2 7})$ \\
\hline a. & Major & 125732.40 & 173794.40 & 81347.21 & 127912.22 \\
& Implements & $(19.70)$ & $(31.08)$ & $(30.60)$ & $(21.19)$ \\
\hline b. & Minor & 505.16 & 352.09 & 165.20 & 464.52 \\
& Implements & $(0.08)$ & $(0.062)$ & $(0.06)$ & $(0.08)$ \\
\hline $\mathbf{( 3 )}$ & Live stock & $\mathbf{8 3 4 0 9 . 3 2}$ & $\mathbf{8 2 7 0 6 . 8 3}$ & $\mathbf{3 9 3 7 6 . 3 5}$ & $\mathbf{8 0 2 4 9 . 7 3}$ \\
& & $\mathbf{( 1 3 . 0 7 )}$ & $\mathbf{( 1 4 . 8 0 )}$ & $\mathbf{( 1 4 . 8 1 )}$ & $(\mathbf{1 3 . 2 9})$ \\
\hline a. & Buffalo & 38479.98 & 48212.46 & 21174.75 & 38339.19 \\
& & $(6.03)$ & $(8.62)$ & $(7.97)$ & $(6.35)$ \\
\hline b. & Cow & 34341.38 & 28702.75 & 14648.29 & 32342.61 \\
& & $(5.38)$ & $(5.13)$ & $(5.51)$ & $(5.35)$ \\
\hline c. & Goat & 9817.07 & 5515.83 & 3553.30 & 8905.47 \\
& & $(1.54)$ & $(0.99)$ & $(1.34)$ & $(1.47)$ \\
\hline d. & Poultry & 770.89 & 275.78 & 00.00 & 662.46 \\
& & $(0.12)$ & $(0.12)$ & $(00.00)$ & $(0.11)$ \\
\hline $\mathbf{( 4 )}$ & Grand total & $\mathbf{6 3 8 2 8 3 . 6 0}$ & $\mathbf{5 5 9 1 0 0 . 5 0}$ & $\mathbf{2 6 5 7 7 6 . 1 0}$ & $\mathbf{6 0 3 4 9 7 . 9 1}$ \\
& & $(\mathbf{1 0 0})$ & $(\mathbf{1 0 0})$ & $(\mathbf{1 0 0})$ & $(\mathbf{1 0 0 )}$ \\
\hline
\end{tabular}

(Figure in parentheses indicate the percentage)

It is also depicted from the table that per farm investment had the positive relationship with size of holding. As it increases with increase in farm size, farm category wise value of farm assets were found to Rs. 357438.80, Rs. 497599.43 and Rs. 523578.99 on marginal, small, and medium size of farms. Similar trend were recorded in case of investment on building, farm machinery and livestock.

\section{Per hectare investment}

Per hectare investment on different size group of farm in the study area are presented in table 5. It is depicted from the table that overall average per hectare investment on farm assets was Rs. 394871.43, Rs. 128378.75 and Rs. 80249.73 on farm building mercenary and livestock, which accounted for 65.43, 21.27 and 13.29 per cent respectively.
Trend of per hectare investment on sample farm are different than the per farm value. It shows the inverse relationship with the size of holding. As its value were recorded to Rs. 638283.60, Rs. 559100.50 and Rs. 265776.10 on marginal, small and medium size group of farm respectively.

It is also clear from the table that per hectare investment on building did not have any definite trend with size of farms, were as investment on other to components i.e. farm machinery and implements and livestock were showed the positive trend with farm size.

The importance of vegetable crops in our country can be judge from the fact that majority of the Indian population is vegetarian. Vegetables are the main source of minerals and vitamins and other nutritive 
ingredients in vegetarian diet. It plays a significant role in balance nutrition and assured the nutritional security to the people since the nutritional security is an important requirement thus special affords on intensification of production and supply of vegetables are necessary with increasing population and negligible scope of growth in net area sown.

Multistage stratified purposive cum random sampling technique was used for the selection for district, block, villages and respondents. Accordingly the Chiraigaon block of Varanasi district were chosen for this study and one hundred respondents from five selected villages of Chiraigaon block were chosen from three categories of farms size i.e. marginal, small and medium. Pre structured schedule were used to collect the primary data from sample farmers with personal interview method and secondary data were collected from official records at block and district offices. Simple tabular and functional analysis of data was done to interpretate the result.

Objective wise results obtained from the analysis of data revealed that among different components of farm structure land holding was found as 0.78 ha. On overall average basis which was $0.56,1.19$ and 2.76 hectare on marginal, small and medium size group of farms. Cropping pattern shows that 35.35 per cent of gross cropped area was covered by different crops in Kharif season were as in Rabi and Zaid season it were 36.06 and 28.58 per cent gross cropped area. Among different crops grown by the sample farmers during a year wheat has covered maximum area 16.18 per cent followed by paddy 14.47 per cent and urd 7.18 per cent? It is also depicted from the table that vegetables have also covered considerable average in all three season as 13.90, 11.01 and 17.32 per cent of gross cropped area in Kharif, Rabi and Zaid season respectively. The vegetable crop considered under study i.e. cauliflower have also covered a sizeable area i.e. 7.14 per cent gross cropped area. A considerable share of vegetable crops in cropping pattern is much suitable for the farm situation of the study area. Because of perishable nature green/fresh vegetables need immediate disposal for which sabji mandi and road and transport are well established and available.

As far as cropping intensity on sample farms is concerned it was found of negative relation with size of holding. The overall average cropping intensity was 255.12 per cent which was maximum at marginal farm 272.32 followed by small and medium size of farms which were 230.25 and 228.26 per cent respectively. High cropping intensity on marginal farm was found because of better land utilization with intensive use of family labour.

Per farm investment on farm assets was Rs. 384486.28 on overall average basis which was maximum Rs. 523578.99 on medium farms followed by Rs. 497599.43 and Rs. 357438.80 on small and marginal farms. Among all three major components per farm investment on building was of negative trend and farm machinery and livestock were having positive trend with holding size. Similar trend was also found in case of per hectare investment on farm assets.

\section{References}

Akter, S., Islam, M.S. and Rahman, M.S. 2011. An economic analysis of winter vegetables production in some selected areas of Narsingdi district. Journal Bangladesh Agricultural University. 9(2): 241-246.

Niwas, Shri and Singh, R.P. 1983. Economics of production of cauliflower in Hinterland of Hissar City. Harayana Agriculture university journals 
research. 13(2): 335-341.

Priscilla, L., and Singh, S.P. 2015. Economics of vegetable production in Manipur. Indian Journal of Economics and Development. 11(4): 933-938.

Raghavendra, R., Natikar, K.V. and Jahagirdar 2008. A study on marketing behavior of cauliflower growers in Belgaum district of Karnataka. Mysore Journal of Agricultural Sciences. 42(1): 92-96.

Tiwari, N.D., and Bhagat, D.V. 2002. An economic analysis of the production of vegetable crops in Rewa District of
Madhya Pradesh. Journal of Soils and Crops. 12(1): 157-159.

Wadhwani, M.K., and Bhogal, T.S. 2003. Economics of production, post-harvest management and price behavior of cole crops in western U.P.-an empirical analysis. Agricultural marketing. 46(1): 10-20.

Ydav, S.M., and Rai, J. 2012. Production and economics of major vegetable crops in district Mirzapur (U.P.) India. Enviorment and Ecology. 30(2): 336339.

\section{How to cite this article:}

Rajeev Kumar, Rajeev Singh, Gyan Prakesh Singh, Harendra Pratap Singh Choudhri, Jitendra Kumar Singh and Santosh Kumar Mishra. 2017. A Study the Farm Asset Structures, Cropping Pattern and Cropping Intensity of Sample Farms. Int.J.Curr.Microbiol.App.Sci. 6(9): 26852694. doi: https://doi.org/10.20546/ijcmas.2017.609.331 